\title{
Magnesium and Uranium isotope composition of the Sturtian Jacoca Formation cap dolomite, Brazil
}

\author{
ROLANDO E. CLAVIJO ARCOS ${ }^{1}$, MATTHEW O. \\ CLARKSON $^{1}$, DEREK VANCE ${ }^{1}$, ALCIDES N. SIAL ${ }^{2}$, \\ MARIUS N. MÜLLER ${ }^{2}$ AND NETTA SHALEV ${ }^{1}$ \\ ${ }^{2}$ Federal University of Pernambuco
}

${ }^{1}$ ETH Zürich

Presenting Author: r.clavijo@erdw.ethz.ch

The Early Cryogenian period is marked by the Sturtian glaciation episode (ca. 720-660 Ma) that triggered a global perturbation to ocean chemistry and to the surface cycles of many elements. However, reconstructing variations in seawater chemistry during the Early Cryogenian remains a challenge. The magnesium and uranium isotope composition of seawater $\left(\delta^{26} \mathrm{Mg}\right.$ and $\delta^{238} \mathrm{U}$ ) have recently been shown to be good tools to reconstruct key Earth-surface processes, such as weathering rates, carbonate precipitation, and seawater anoxia. Dolomite has been suggested as a promising archive for $\delta^{26} \mathrm{Mg}$ and $\delta^{238} \mathrm{U}$ values of past seawater, but the fact that, in many cases, dolomite forms in sediment-buffered conditions complicates the interpretation of its isotopic signature. Here, we study the Sturtian Jacoca Formation cap dolomite member ( $1.5 \mathrm{~m}$-thickness), underlain by the Jacarecica Formation diamictite. The goals of this study are: (1) to identify the factors determining the $\delta^{26} \mathrm{Mg}$ and $\delta^{238} \mathrm{U}$ values of this cap dolomite; and (2) to assess if these isotope values can be used to reconstruct the $\delta^{26} \mathrm{Mg}$ and $\delta^{238} \mathrm{U}$ of Early Cryogenian seawater. To this end, we measure $\mathrm{Mg}$ and $\mathrm{U}$ isotope compositions of dolomites sampled from 3 profiles (ca. $1 \mathrm{~m}$ apart), as well as different generations of dolomite within single samples. These measurements are supplemented by chemical composition, mineralogical (XRD), and petrographic analyses. The samples exhibit a narrow range of $\mathrm{Mg} / \mathrm{Ca}$ molar ratios $(0.84$ - 1.04), which along with XRD and petrographic analysis, indicate a dolomite-dominated carbonate mineralogy. The $\delta^{26} \mathrm{Mg}$ values of the cap dolomite samples range between $-1.77 \%$ and $-0.91 \%$. Through the basal $6 \mathrm{~cm}$ above the contact with the underlying diamictite, the $\delta^{26} \mathrm{Mg}$ increases from $-1.66 \%$ oto $-0.91 \%$. This may suggest a local ${ }^{26} \mathrm{Mg}$-enrichment within the precipitating solution. Above this, the $\delta^{26} \mathrm{Mg}$ value decreases back to $\sim-1.7 \%$ and remains similar up to the highest sample taken $(100 \mathrm{~cm})$. This may suggest that the system was more seawater-buffered for the upper part of the unit relative to the basal part. Such seawater-buffered dolomite $\delta^{26} \mathrm{Mg}$ may be used for reconstructing Early Cryogenian seawater $\delta^{26} \mathrm{Mg}$. 